\title{
Herbaceous Forage Legumes Adaptation in Acidic Soils in South-Kivu, D. R. Congo
}

\author{
M. M. D. Katunga (Corresponding author) \\ International Center For Tropical Agriculture (CIAT), Bukavu, D. R. Congo \\ Current address: National Institute of Studies and Agriculture Researches (INERA) Mulungu \\ Bukavu, D. R. Congo \\ E-mail: katungamusale@yahoo.fr
}

J. B. B. Muhigwa

Université Officielle de Bukavu, D. R. Congo

E-mail: jeanmuhigwa@yahoo.fr

Received: August 14, 2014 Accepted: October 26, $2014 \quad$ Published: November 4, 2014

Doi: 10.5296/jab.v3i1.6548 URL: http://dx.doi.org/10.5296/jab.v3i1.6548

\begin{abstract}
In D. R. Congo, agriculture is still managed in extensive system with crop integration especially in South-Kivu Province. Demographic pressure on the land is highly due to unequal distribution.

The objective of this study is to test adaptation of improved herbaceous forage legumes selected in Tropical America by "Centro International de Agricultura Tropical" (CIAT). Agronomic performance and farmer participatory evaluation in using various agroecological zones in South-Kivu, were used to draw a model for similar areas. Forages were installed randomly in the blocks with 3 replicates. In spite of the acidic soils, forages recommended were, S. guianensis 11995, S. guianensis Cook, C. molle and D. intortum. The second step should be to adapt these forages in the farmers cropping systems. The seasons didn't influence in general the yield production. All the accessions of $V$. unguiculata and C. ternatea did not adapt anywhere and $C$. brasiliensis was sensitive to diseases and insects.
\end{abstract}

Keywords: Herbaceous forage legumes, Adaptation, Farmers participatory evaluation, D. R. Congo 


\section{Introduction}

The world population passing seven billion in 2011 can exceed nine billion by 2050 . Human consumption will increase and the challenge will be to face malnutrition and ensure a sustainable food production and environment. While the intensification pathway would require a significant input of fertilizers and agro-chemicals, the environmental costs of these inputs are likely to be small compared with the impacts of increases in greenhouse gases and loss of biodiversity form the land expansion pathway (Keating et al., 2013). Designing ecologically intensive systems imposes on agronomists the need to move beyond optimizing current processes, to design of the structures that support such processes (and new ones) in space and time. The diversity, special heterogeneity and temporal dynannics of smallholder farming systems in the humid highlands of Africa call for the flexible, adaptive targeting of politics, management practices and technologies (Titonell, 2013). In D.R. Congo, agriculture is still managed in extensive system with crop integration especially in South-Kivu Province (Cox, 2012; Ouma et al., 2012). Demographic pressure on the land is highly due to unequal distribution. However, the environment enduring insecurity, wars, animals looting and poverty challenges any new research initiative (Maass et al., 2012). There are low crop productions due to poor soil management, small homelands of farmers, lack of extension services, leading to alarming nutritional status (Katunga, 2004). Livestock productivity is low, especially during the dry season. The forage crops are not practiced yet to feed small animals (Katunga, 2013) whereas improved forages could play an important rolle to both enhance livestock production and improve soil fertility and also prevent from soil erosion. This study aimed at testing adaptation of improved herbaceous forage legumes selected in Tropical America by "Centro International de Agricultura Tropical" (CIAT). Agronomic performance and farmer participatory evaluation in using various agroecological zomes in South-Kivu, were used to draw a model for similar areas.

\section{Material and Methods}

\subsection{Agronomic Evaluation}

The trial was installed in October, 2010 at both sites with poor soils. Table 1 indicates the location and some characteristics of the sites.

Table 1. Location of the experimental sites and some characteristics

\begin{tabular}{llllll}
\hline Site & Latitude & Longitude & $\begin{array}{l}\text { Elevation } \\
\text { (m asl) }\end{array}$ & Soil fertility & $\begin{array}{l}\text { Population } \\
\text { (number of } \\
\text { inhabitants) }\end{array}$ \\
\hline Nyangezi & $2.88^{\circ} \mathrm{S}$ & $27.03^{\circ} \mathrm{E}$ & 1580 & $\mathrm{pH} \mathrm{3.94,} \mathrm{CEC} \mathrm{3.0}$ & $39,782^{*}$ \\
Tubimbi & $2.79^{\circ} \mathrm{S}$ & $23.59^{\circ} \mathrm{E}$ & 1100 & $\mathrm{pH} \mathrm{4.45,} \mathrm{CEC} \mathrm{4.0}$ & $23,630^{*}$ \\
\hline
\end{tabular}

* (SNS 2011).

Seeds of the experimental fodders came from CIAT Columbia. They were Canavalia brasiliensis CIAT 17009, Centrosema molle CIAT 15160, Clitoria ternatea CIAT 20692, Lablab purpureus (CIAT 21603 and CIAT 22759), Stylosanthes guianensis (CIAT 11995 and 


\section{Macrothink}

ILRI 4 Cook), Vigna unguiculata (CIAT IT95K52-34, CIAT IT97K1069-6 and CIAT IT98K131-2) and Desmodium intortum as a local control. Four handshakes of cow manure were placed in the hole before the plantation at the two sites. Forages were installed randomly in the blocks with 3 replicates. Every plot measured $3 \mathrm{~m} \times 3 \mathrm{~m}$. The seedling were set in line with a spacing of $0.25 \mathrm{~m}$ and $0.5 \mathrm{~m}$ between lines. At average $50 \%$ flowering in all plots, regularization cuttings were made in January, 2011 in Nyangezi and Tubimbi. Leaves were removed off stems and were weighed separately for the herbaceous with little stems (Canavalia brasiliensis, Clitoria ternatea, Lablab purpureus, Vigna unguiculata). After every harvest, all other lines of the useful plot and borders were cut (Schultz-Kraft \&Toledo, 1990; Rabaoc, 1998). Six overall cuttings were made over eight weeks. A homogeneous fresh sample of about $300 \mathrm{~g}$ leaves and $300 \mathrm{~g}$ of stems by accession and / or specie was taken at every harvest and was put until constant weight during at least three months in a sun drier that reached $40-45^{\circ} \mathrm{C}$ in brightened time. The mean fresh leaves and stems (only for the herbaceous with little stems) yield (MFLSY) in $\mathrm{kg} \mathrm{ha}^{-1}=$ Fresh leaves and / or stems for some forage $(\mathrm{g}) \times$ Dry mater $(\%) / \mathrm{Su}\left(\mathrm{m}^{2}\right) \times 10$, (Katunga, 2004), Su is the net plot size $\mathrm{m}^{2}$. Samples have been analyzed on reflectance spectroscopy for nutrient contents (DM, OM, CP, $\mathrm{ADF}, \mathrm{ADL}$ and TIVOMD) at the International Livestock Research Institute (ILRI) in Addis-Abeba, Ethiopia.

\subsection{Farmers Participatory Evaluation}

Farmers evaluation was done during the rainy and dry season at both sites with 5 women and 5 men per location and season indicating preferences according to own criteria. Farmers selected plots by dropping a white paper. Data were presented as ranks of preference at the location. After the choice of forages, the two teams gathered to discuss and reach a gender consensus (Stür et al., 2002).

\subsection{Data Analysis}

Descriptive statistics were computed and differences of MFLSY were established by Analysis of variance (ANOVA), graphs in STATVIEW software, Cluster analyses and Correspondence analyses in Past Software.

\section{Results}

3.1 Agronomic Evaluation

\subsection{Nutritive Values of Forages}


Table 2. Chemical analyses of forages at both sites (\%)

\begin{tabular}{lccccccccccc}
\hline & \multicolumn{1}{c}{ Nyangezi } & \multicolumn{1}{c}{ Tubimbi } \\
\hline $\begin{array}{l}\text { Légumineuses } \\
\text { herbacées }\end{array}$ & DM* & OM & CP & ADF & TIVOMD & DM & OM & Cp & ADF & TIVOMD \\
C. brasiliensis 17009 & 22.7 & 82.6 & 23.5 & 30.5 & 75.5 & 21.7 & 81.2 & 22.7 & 31.3 & 73.3 \\
C. molle 15160 & 29.2 & 90.9 & 11.4 & 36.1 & 66.4 & 25.1 & 87.2 & 19.3 & 38.8 & 68.8 \\
C. ternatea 20692 & 22.4 & 89.6 & 22.5 & 30.7 & 72.8 & 19.6 & 94.3 & 14.9 & 40.3 & 61.4 \\
D. intortum & 23.4 & 91.5 & 16.3 & 33.3 & 63.8 & 21.3 & 89.9 & 17.5 & 34.5 & 64.5 \\
L. purpureus 22759 & 21.1 & 87.9 & 25.5 & 24.9 & 74.3 & 24.3 & 86.6 & 24.9 & 28.2 & 74.1 \\
L. purpureus 21603 & 22.4 & 87.5 & 25.4 & 27.7 & 72.5 & 23.7 & 88.5 & 25.3 & 28.4 & 74.2 \\
S. guianensis 11995 & 25.1 & 89.9 & 19.2 & 39.8 & 62.8 & 23.2 & 89.9 & 20.1 & 38.9 & 65.9 \\
S. guianensis Cook & 23.5 & 90.3 & 20.1 & 43.1 & 60.7 & 24.4 & 91.1 & 22.2 & 36.9 & 64.4 \\
V. unguiculata 131-2 & 32.9 & 87.7 & 26.2 & 31.7 & 75.2 & 32 & 85.8 & 24.2 & 34 & 74.7 \\
V. unguiculata 52-34 & 35 & 83.9 & 27.4 & 33.4 & 73.8 & 32.9 & 85 & 24.6 & 35.9 & 73 \\
V. unguiculata $1069-6$ & 33 & 83.7 & 26.7 & 32.6 & 74.7 & 33.9 & 85.6 & 25.3 & 34.5 & 71.2 \\
\hline
\end{tabular}

$* \mathrm{DM}=$ Dry mater, $\mathrm{OM}=$ Organic matter, $\mathrm{CP}=$ Crude proteins, $\mathrm{ADF}=$ Acid Detergent Fiber, TIVOMD = True In Vitro Organic Mater Digestibility.

The nutritive values of the forages were in general very good, $\mathrm{CP}$ of all the forages varied in Nyangezi between 16 to $27 \%$ except $11.4 \%$ for $C$. molle, but it was very good in Tubimbi. Digestibility is very good at both sites. In Nyangezi ADF is in general lower than in Tubimbi, good forages reached at least $30 \%$.

\subsection{Diseases and Insects}

Table 3 shows the scores of diseases and insects.

Table 3. Ranks of diseases and pests

\begin{tabular}{|c|c|c|c|c|}
\hline \multirow{2}{*}{ Forage herbaceous legumes } & \multicolumn{2}{|l|}{ Nyangezi } & \multicolumn{2}{|l|}{ Tubimbi } \\
\hline & Diseases & Pests & Diseases & Pests \\
\hline C. brasiliensis 17009 & 3 & 2 & 3 & 2 \\
\hline C. molle 15160 & 2 & 2 & 1 & 1 \\
\hline C. ternatea 20692 & 3 & 2 & 3 & 1 \\
\hline D. intortum & 2 & 2 & 2 & 2 \\
\hline L. purpureus 21603 & 3 & 2 & 2 & 2 \\
\hline L. purpureus 22759 & 2 & 2 & 2 & 2 \\
\hline S. guianensis 11995 & 1 & 1 & 1 & 1 \\
\hline S. guianensis Cook & 1 & 1 & 1 & 1 \\
\hline V. unguiculata 52-34 & 4 & 3 & 4 & 2 \\
\hline V. unguiculata 1069-6 & 4 & 3 & 4 & 2 \\
\hline V. unguiculata $131-2$ & 4 & 3 & 4 & 2 \\
\hline
\end{tabular}


In general, the forages were not considerably attacked by diseases and pestts. Fodders that had the score 1 meaning without impact of diseases and pests in Nyangezi and Tubimbi were $S$. guianensis and $S$. guianensis Cook. Forages fairly attacked by diseases and insects, rank 2 in Nyangezi were L. purpureus 22759, C. molle and D. intortum and for Tubiimbi D. intortum, $L$. purpureus 21603 and L. purpureus 22759. Fodders most attacked by diseases and insects, ranks 3 and 4 were also observed in Nyangezi occurred for $3 C$. brasiliemsis $C$. ternatea, $L$. purpureus 21603 and pests V. unguiculata 1069-6, V. unguiculata 131-2 and V. unguiculata 52-34. In Tubimbi with the rank 3 , for diseases were $C$. brasiliensis and $C$. ternatea, the rank 4 was observed in the two sites on diseases with $V$. unguiculata 1069-6, V. unguiculata 131-2 and $V$. unguiculata 52-34.

The following figures show the height and recovery of forages at the sites.

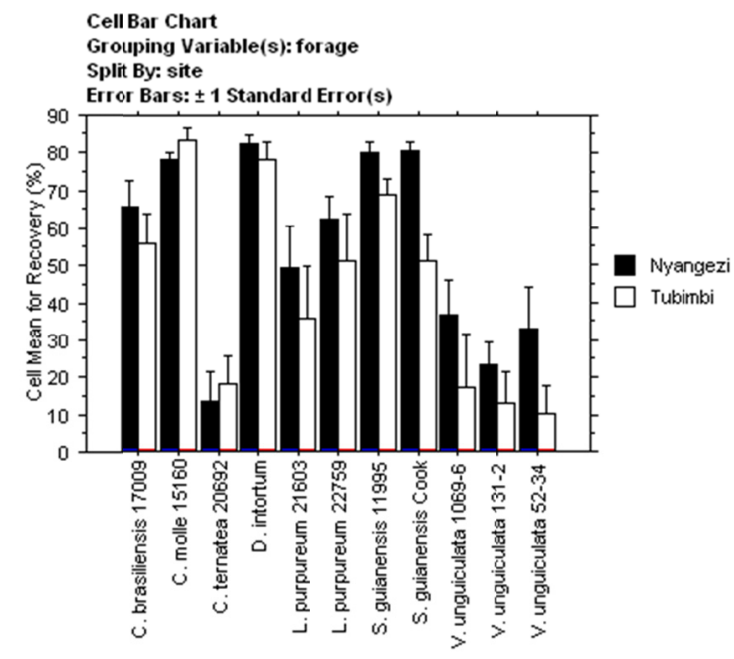

Figure 1 . The recovery of the forages $(\%)$

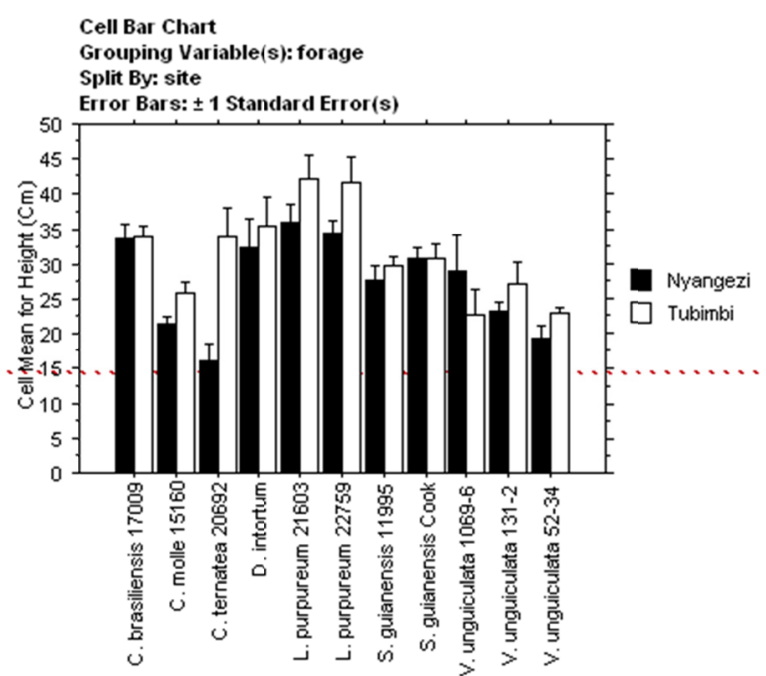

Figure 2. The height $(\mathrm{cm})$ of forages

In Nyangezi the best recovery was performed by D. intortum, C. brasiliensis, $C$. molle, $L$. purpureus 22759, L. purpureus 21603, S. guianensis 11995, S. guianensis Cook and in Tubimbi C. brasiliensis, C. molle, D. intortum, L. purpureus 22759, S. guianensis 11995 and $S$. guianensis Cook. Forages with a better height were in Nyangezi C. brasiliensis, $D$. intortum, L. purpureus 22759, S. guianensis 11995, S. guianensis Cook and V. unguiculata 1069-6 and Tubimbi C. brasiliensis, C. molle, D. intortum, L. purpureus 22759, S. guianensis 11995, S. guianensis Cook and V. unguiculata 131-2. In Nyangezi there is a significant difference of recovery rates between the forages $(\mathrm{P}<0.05)$ whereas for the height there was no significant difference $(\mathrm{P}>0.05)$. In Tubimbi the rates of recovery and height did not differ between the forages $(\mathrm{P}>0.05)$.

\subsection{Biomass Production}

Table 4 shows the total biomass fresh and stems yield according to seasons. 
Table 4. Yield production per season (MFLSY means $\mathrm{kg} \mathrm{ha}^{-1}$ )

\begin{tabular}{lllll}
\hline Herbaceous legumes & \multicolumn{1}{c}{$\begin{array}{c}\text { Rainy season } \\
\text { Nyangezi }\end{array}$} & \multicolumn{1}{c}{ Tubimbi } & \multicolumn{1}{c}{$\begin{array}{c}\text { Nyangezi } \\
\text { C. brasiliensis } 17009\end{array}$} & \multicolumn{1}{c}{ Tubimbi } \\
\hline C. molle 15160 & $1000.0 \pm 353.4 \mathrm{ab}$ & $1226.0 \pm 677.1 \mathrm{a}$ & $572.0 \pm 22.1 \mathrm{ab}$ & $1814.0 \pm 1263.2 \mathrm{a}$ \\
C. ternatea 20692 & $62.0 \pm 89.3 \mathrm{bc}$ & $130.8 \pm 261.6 \mathrm{bc}$ & $\mathrm{n} . \mathrm{m}^{*}$ & $\mathrm{n} . \mathrm{m}$ \\
D. intortum & $1316.0 \pm 1147.8 \mathrm{ab}$ & $918.0 \pm 797.3 \mathrm{ab}$ & $392.0 \pm 221.4 \mathrm{bc}$ & $573.0 \pm 457.9 \mathrm{~b}$ \\
L. purpureus 21603 & $368.0 \pm 386.8 \mathrm{bc}$ & $182.0 \pm 137.7 \mathrm{bc}$ & $47.0 \pm 0 \mathrm{bc}$ & $\mathrm{n} . \mathrm{m}$ \\
L. purpureus 22759 & $568.0 \pm 402.1 \mathrm{~b}$ & $484.0 \pm 429.5 \mathrm{~b}$ & $563.0 \pm 218.9 \mathrm{~b}$ & $\mathrm{n} . \mathrm{m}$ \\
S. guianensis 11995 & $1807.0 \pm 1639.7 \mathrm{a}$ & $1055.0 \pm 472.7 \mathrm{ab}$ & $1188.0 \pm 204.5 \mathrm{a}$ & $325.0 \pm 363.9 \mathrm{ab}$ \\
S. guianensis Cook & $1593.0 \pm 809.7 \mathrm{ab}$ & $1128.0 \pm 660.2 \mathrm{ab}$ & $721.0 \pm 370 \mathrm{ab}$ & $466.0 \pm 191.7 \mathrm{ab}$ \\
V. unguiculata $1069-6$ & $88.0 \pm 94.5 \mathrm{bc}$ & $64.0 \pm 59.5 \mathrm{bc}$ & $\mathrm{n} . \mathrm{m}$ & $\mathrm{n} . \mathrm{m}$ \\
V. unguiculata $131-2$ & $42.0 \pm 16.1 \mathrm{bc}$ & $65.0 \pm 80.4 \mathrm{bc}$ & $\mathrm{n} . \mathrm{m}$ & $\mathrm{n} . \mathrm{m}$ \\
V. unguiculata $52-34$ & $190.0 \pm 171.3 \mathrm{bc}$ & $132.0 \pm 193.4 \mathrm{bc}$ & $\mathrm{n} . \mathrm{m}$ & $\mathrm{n} . \mathrm{m}$ \\
\hline Lsd (p<0,05) & 1130.5 & 689.2 & 580.2 & 1162.3 \\
\hline
\end{tabular}

n.m*=not mentioned.

According to seasons, Turkey test gathers means in two classes. There is a highly significant difference $(\mathrm{P}<0.001)$ between the production of the biomass in rainy season in Nyangezi and Tubimbi. During the dry season, there is a significant difference $(\mathrm{P}<0.05)$ between the production of fodders in the dry season. In Tubimbi there is no difference $(\mathrm{P}>0.05)$ between the production of fodders in the dry season. At both sites and according to seasons, the means are classified in two groups.

Forages with the best yield in the rainy season were the same at both sites: C. brasiliensis, $C$. molle, D. intortum, S. guianensis 11995 and S. guianensis Cook. In the dry season the outcome was the same except for $C$. brasiliensis which performed well onlly in Tubimbi. 


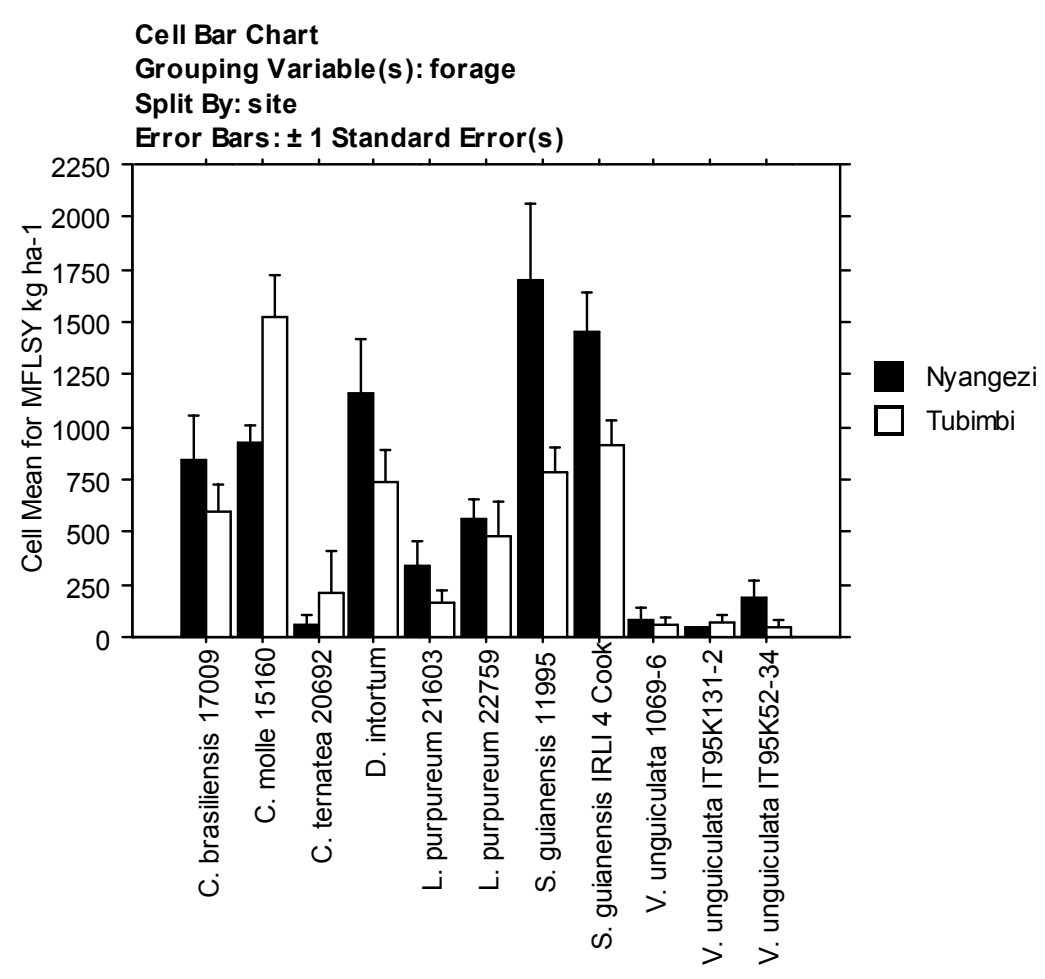

Figure 3. Mean fresh leaves and stems yield per site

The best yield production of forages were in Nyangezi C. brasiliensis, C. molle, D. intortum, S. guianensis 11995 and S. guianensis Cook and in Tubimbi C. molle, D. intortum, S. guianensis 11995 and $S$. guianensis Cook. In Nyangezi there is a significant difference of fodders yield $(\mathrm{P}<0.05)$ but not in Tubimbi $(\mathrm{P}>0.05)$.

Figure 4 shows the yield production of forages at both sites. 


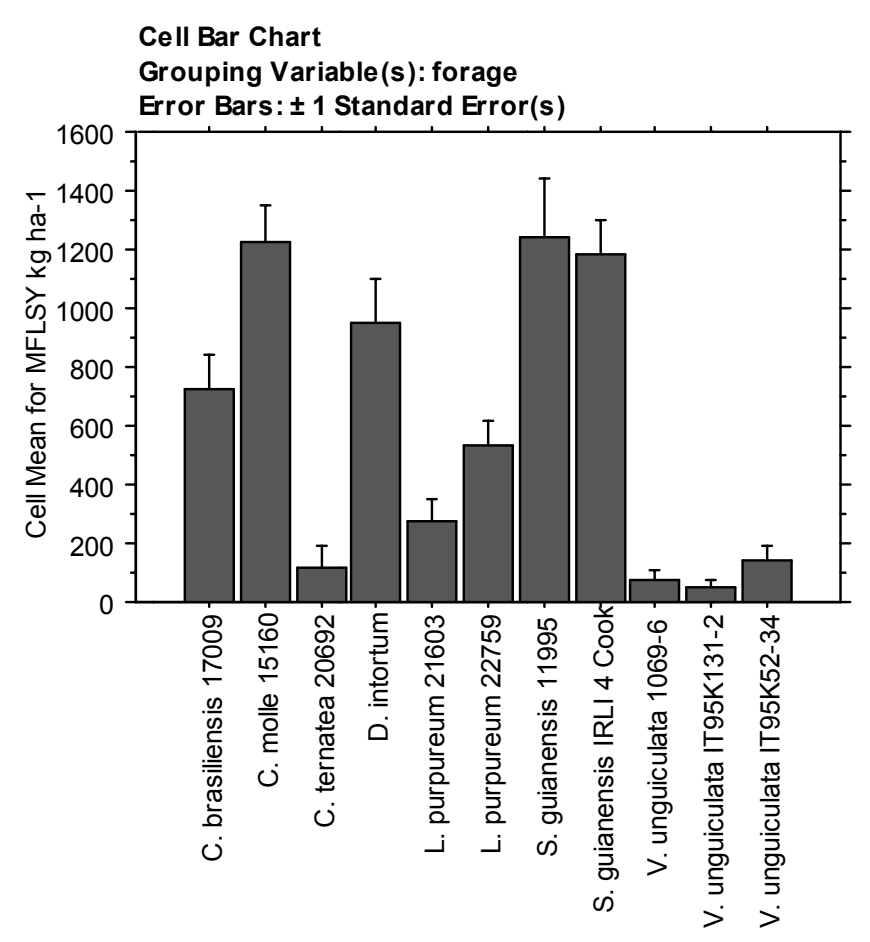

Figure 4. MFLSY in both the sites

At both the sites, the best yield forages were C. molle, D. intortum, S. guianensis 11995 and $S$. guianensis Cook. There was a significant difference between the yield production of forages $(\mathrm{P}<0.05)$.

Figure 5 shows the clusters of forages according quantitative variables.

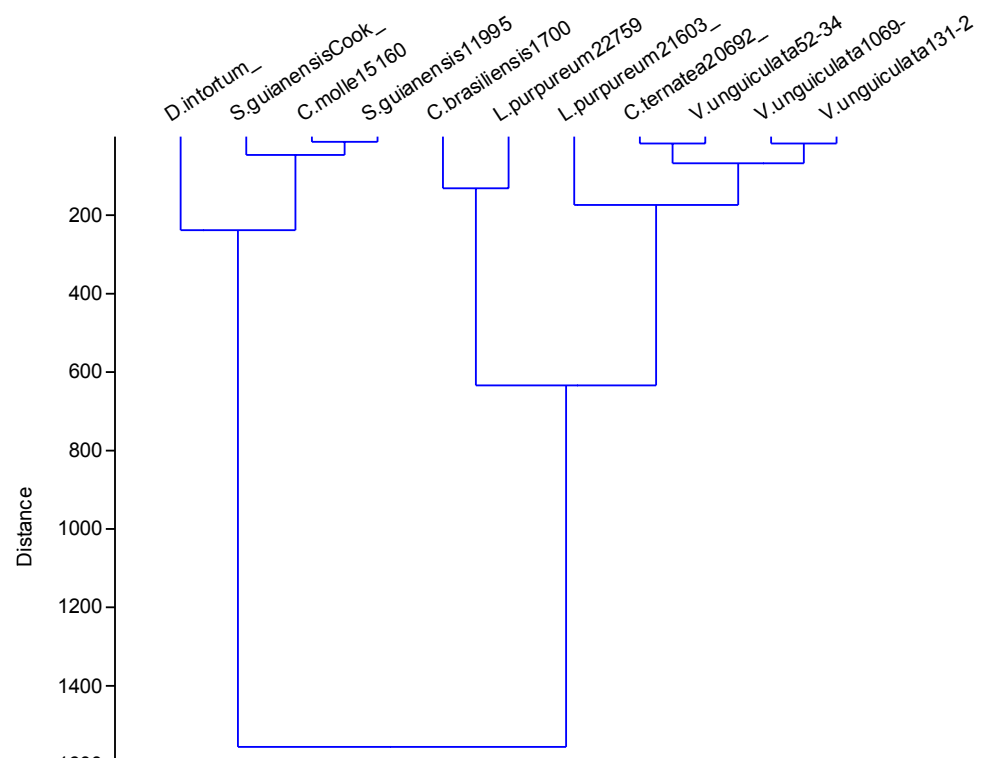

Figure 5. Cluster of forages according quantitative variables

This cluster involved the following quantitative variables : MFLSY, recovery, height, soil $\mathrm{pH}$ 
and Cp. The eigen value of the two first axes was $99.9 \%$.

The figure shows that fodders are classified in two groups in which the best includes $D$. intortum, S. guianensis 11995, S. guianensis Cook and C. molle.

3.5 Participatory Evaluation Of Forage Herbaceous Legumes

Table 5 shows the forage choices of the farmers.

Table 5. Ranks of farmers' choice

\begin{tabular}{lllll}
\hline Forage herbaceous legumes & Rainy saison & \multicolumn{3}{c}{ Dry saison } \\
\cline { 2 - 5 } & Nyangezi & Tubimbi & Nyangezi & Tubimbi \\
\hline C. brasiliensis 17009 & 1 & 1 & 3 & 2 \\
C. molle 15160 & 0 & 4 & 1 & 1 \\
C. ternatea 20692 & 0 & 0 & 0 & 0 \\
D. intortum & 0 & 0 & 0 & 3 \\
L. purpureus 21603 & 4 & 0 & 0 & 0 \\
L. purpureus 22759 & 0 & 0 & 0 & 0 \\
S. guianensis 11995 & 3 & 3 & 2 & 4 \\
S. guianensis Cook & 2 & 2 & 4 & 0 \\
V. unguiculata $52-34$ & 0 & 0 & 0 & 0 \\
V. unguiculata $131-2$ & 0 & 0 & 0 & 0 \\
V. unguiculata $1069-6$ & 0 & 0 & 0 & 0 \\
\hline
\end{tabular}

*n,m.: not mentioned

In general, the farmer's choice of forages is not different between the two seasons in both sites. The forages chosen are essentially $C$. brasiliensis, $S$. guianensis Cook, $C$. molle, and $S$. guianensis 11995. Figure 6 shows the correspondence analysis of the fodders chosen by farmers while taking account of gender and the season. 


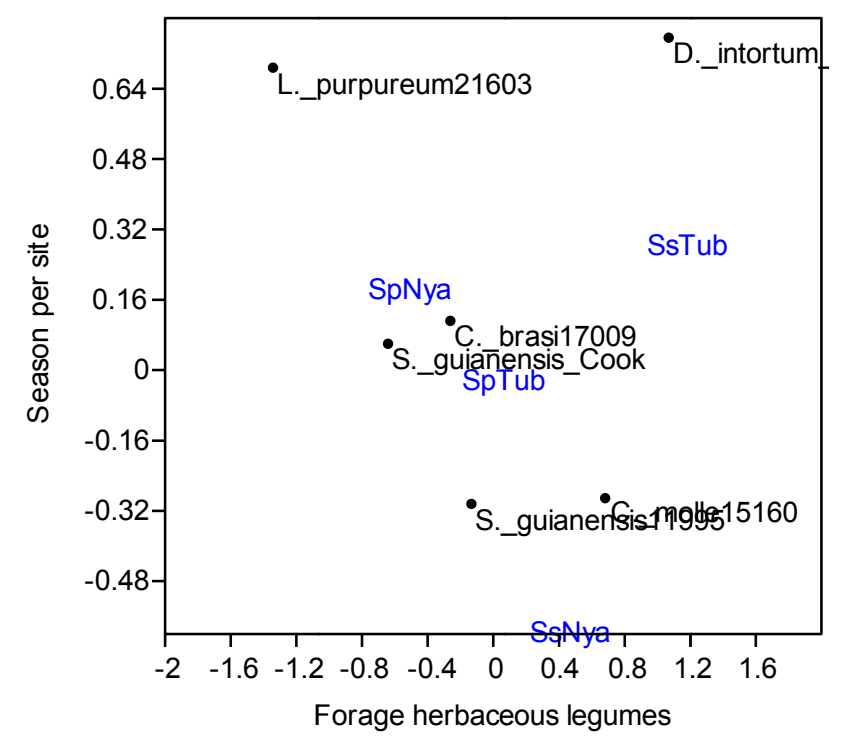

Figure 6. Correspondence analysis of farmer choices

The eigen values of the two first axes were $90.5 \%$. The qualitatives variables observed were: NyaSp=Nyangezi in rainy season, TubSp=Tubimbi in rainy season, NyaSs=Nyangezi in dry saison, TubSs=Tubimbi in dry season.

Figure 6 shows that the choice of C. brasiliensis and S. guianensis Cook was high in the rainy season at both sites; S. guianensis 11995 and C. molle in Nyangezi during the dry season.

\section{Discussion}

In the acidic soils of South-Kivu, S. guianensis reached a yield production similar to that in Rwanda (Barahenda et al., 2007). All legume plant, counts among which S. guianensis decreased drastically with zero counts during the $3^{\text {th }}$ season in Zimbabwe (Mugabe et al., 2004). Compared to Central America Canavalia brasiliensis yield production (Douxchamps et al., 2008) was more than double in South-Kivu. In South Africa some accessions of Lablab purpureus produced between 1000 to $7000 \mathrm{~kg} / \mathrm{ha}$ (Ayisi et al., 2004), which suggests that South-Kivu yield production is among the lowest. Forages with the best yield of biomass were C. brasiliensis, C. molle, D. intortum, S. guianensis 11995 and S. guianensis Cook in Nyangezi and they were the same species without $C$. brasiliensis in Tubimbi. This last one was among the forages more attacked by diseases and insects. As C. brasiliensis adapted well in Nyangezi and Tubimbi but its sensitivity to diseases leads to scepticism (Katunga, 2013). All the accessions of $V$. unguiculata and $C$. ternatea were not adapted anywhere. Among the forages recommended to farmers in Zimbabwe were D. intortum, L. purpureus (Nyoka et al., 2004). There was no significant difference between the rainy and the dry season. In the participatory evaluation, the forages chosen by farmers were essentially $C$. brasiliensis, $S$. guianensis Cook, C. molle, and S. guianensis 11995. The choices of fodders by farmers are generally identical with agronomic results. This observation has also been made here in South-Kivu on cassava-legumes intercropping system (Pypers et al., 2010).

\section{Conclusion}

In spite of the acidic soils, forages recommended were, S. guianensis 11995, S. guianensis 
Cook, $C$. molle and D. intortum. The second step should be to adapt these forages in the farmers cropping systems. The seasons didn't influence in general the yield production. All the accessions of $V$. unguiculata and $C$. ternatea did not adapt anywhere and $C$. brasiliensis was sensitive to diseases and insects. Farmers participatory evaluation should be a good indicator for agronomists and also a way to early involve farmers in the innovations.

\section{References}

Ayisi, K. K., Bopape, M. P., \& Pengelly, B. C. (2004). Assessment of the Variation in Growth and Yield of Diverse Lablab (Lablab purpureus) Germplasm in Limpopo Province, South Africa" In Tropical legumes for sustainable farming systems in southern Africa and Australia, edited by A.M. Whitbread and B.C. Pengelly, ACIAR Proceedings no. 115.

Barhahenda, M., Shem, M. N., Kanuya, N. L., Ntababeza, I., Gasana, J., Uwimana, G., .. Uwumukiza, D. (2007). Yield potential of grass-legume pastures under differen management conditions. Isar Rwanda Research of Animal Sciences, 1(2), 59-61.

Cox, T. P. (2011). Farming in the battlefield: the meanings of war, cattle and soil in South Kivu. Democratic Republic of the Congo. Disasters, 36(2), 233-248. http://dx.doi.org/10.1111/j.1467-7717.2011.01257.x

Douxchamps, S., van der Hoek, R., Benavidez, A., Humbert, F. L., Uehlinger, N., Mena, M., ... Oberson A. (2008). Realizing the benefits of Canavalia brasiliensis in smallholder crop-livestock systems in the hillsides of Central America Annual report Tropical forage program CIAT Columbia, p. 184.

Katunga, M. M. D., et Compère, R. (2000). Comparaison de certaines méthodes permettant l'estimation de la valeur agrostologique; Cas du pâturage Pilet à Corroie-le-Château (Belgique). Cahiers du CERPRU n 14, 2000 Bukavu, RDC, pp. 37-42.

Katunga, M. M. D. (2013). Adaptation and participatory forage leguminous in a system of raising integrating the rabbit and the guinea pig to the South-Kivu, R. D. Congo, Ph. D. thesis, 2013, 212 p. Faculty of veterinary medicine University of Lubumbashi.

Keating, B. A., Carberry, P. S., \& Dixon, J. (2013). Agriculture intensification and the food security challenge in sub-Saharan Africa In Agro-ecological intensification of agriculture systems in the African highlands, pp. 20-35

Mugabe, P. H., Majee, D., Poshiwa, X., Chigariro, B., Ndlovu, B., Washayanyika, F., \& Mukombe, N. (2004). Evaluation of Herbaceous Fodder Legumes Introduced into Communally Managed Rangelands in Zimbabwe In Tropical legumes for sustainable farming systems in southern Africa and Australia, edited by A.M. Whitbread and B.C. Pengelly ACIAR Proceedings No. 115, (Printed version published in 2004 pp. 51-57)

Nyoka, R., Chikumba, N., Chakoma, I., Mazaiwana, P., Mukombe, N., \& Magwenzi, N. (2004). Evaluation and Screening of Fodder Legumes for Sustainable Integration into CropLivestock Farming Systems of Wedza District In Tropical legumes for sustainable farming systems in southern Africa and Australia, edited by A.M. Whitbread and B.C. Pengelly, ACIAR Proceedings No. 115, (Printed version published in 2004 pp. 58-63). 


\section{Macrothink}

Ouma, E., Birachi, E., Pypers, P., Van Lauwe, B., Ekesa, B., Blomme, G., ... Vigheri, N. P. "CIALCA Baselines Survey", CIALCA Technical Report 17, CIAT, IITA, Bioversity International, Nairobi Kenya and Ibandan Nigeria.

Pypers, P., Sanginga, J. M., Kasereka, B., Walangululu, M., \& Van Lauwe, B. (2010). Increasing productivity through integrated soil fertility management in cassava-legumes intercropping system in the highlands of Sud-Kivu DRC Field crops Research

[RABAOC] Réseau de recherches en alimentation du bétail en Afrique Occidentale et Centrale. (1998). Rapport de synthèse Rabaoc, CIRAD-EMVT Rapport no 98-044, CIAT, ILRI et CORAF, p. 88.

Schultz-Kraft, R., \& Toledo, J. M. (1990). Methodology for the agronomic evaluation of fodder plants in regional trails of the west African fodder evaluation network (WAFNET). Second workshop, Avetonou, Togo, pp. 16-21.

[SNS] Service National des Statistiques. (2011). Rapport annuel, Sud-Kivu R. D. Congo.

Stür, W. W., Horne, P. M., Gabunada Jr., F. A., Phengsavanh, P., \& Kerridge, P. C. (2002). Forage options for smallholder crop-animal systems in Southeast Asia: working with farmers

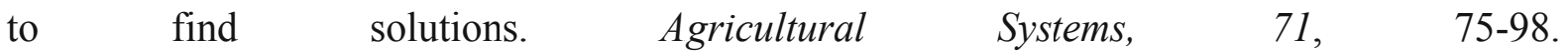
http://dx.doi.org/10.1016/S0308-521X(01)00037-3

Titonell, P. (2013). Towards ecologically intensive smallholder farming systems Design, scales and trade-offs evaluation In Agro-ecological intensification of agriculture systems in the African highlands, pp. 133-144.

\section{Copyright Disclaimer}

Copyright reserved by the author(s).

This article is an open-access article distributed under the terms and conditions of the Creative Commons Attribution license (http://creativecommons.org/licenses/by/3.0/). 